\title{
Forage potential of native ecotypes of Paspalum notatum and $P$. guenoarum
}

\author{
MARCELO G. STEINER ${ }^{1}$, MIGUEL DALL'AGNOL ${ }^{2}$, CARLOS NABINGER $^{2}$, \\ SIMONE M. SCHEFFER-BASSO ${ }^{3}$, ROBERTO L. WEILER ${ }^{2}$, CARINE SIMIONI ${ }^{2}$, \\ MARIA TERESA SCHIFINO-WITTMANN ${ }^{2}$ and ÉDER A.M. DA MOTTA ${ }^{1}$ \\ ${ }^{1}$ Programa de Pós-Graduação em Zootecnia, Faculdade de Agronomia, Universidade Federal do \\ Rio Grande do Sul, Av. Bento Gonçalves, 7712, 91501-970 Porto Alegre, RS, Brazil \\ ${ }^{2}$ Departamento de Plantas Forrageiras e Agrometeorologia, Faculdade de Agronomia, Universidade \\ Federal do Rio Grande do Sul, Av. Bento Gonçalves, 7712, 91501-970 Porto Alegre, RS, Brazil \\ ${ }^{3}$ Instituto de Ciências Biológicas, Universidade de Passo Fundo, Rodovia BR 285, \\ Km 292,7, s/n, São José, 99001-970 Passo Fundo, RS, Brazil
}

Manuscript received on September 30, 2016; accepted for publication on March 14, 2017

\begin{abstract}
The Paspalum genus includes several species that are important for livestock in Rio Grande do Sul, such as $P$. notatum and $P$. guenoarum, typical of native pastures of the Pampa biome. The aim of this study was to investigate forage production and chemical composition of four ecotypes of these species in relation to the cv. 'Pensacola' (P. notatum). Ecotypes of P. guenoarum (Azulão and Baio) and P. notatum (André da Rocha and Bagual) and the cv. 'Pensacola' were evaluated for two years, during which four cuts/year were made. The work was carried out under field conditions at the Agronomic Experimental Station of the Federal University of Rio Grande do Sul ( $\left.30^{\circ} 05^{\prime} \mathrm{S} ; 51^{\circ} 39^{\prime} \mathrm{W}\right)$, in a completely randomized design. $P$. guenoarum stood out for higher productivity and greater tolerance to cold; the Azulão ecotype showed more autumn production in relation to the other ecotypes. Crude protein content ranged from 14 (Baio) to $15 \%$ ('Pensacola'); for neutral detergent fiber, the variation was 68 (Azulão) to $71 \%$ ('Pensacola') and for acid detergent fiber there was a variation of 38 ('Pensacola') to $43 \%$ (Baio). The data demonstrates the potential of native genotypes for use as cattle feeding in southern Brazil.
\end{abstract}

Key words: Seasonality, fiber, forage production dry matter, crude protein.

\section{INTRODUCTION}

The species of Paspalum L. occur in almost all grasslands of the Brazilian's ecosystems and are predominant in many of them, in which they are responsible for most of the forage (Nabinger 2006). Among them, we highlight $P$. notatum Flügge (Bahiagrass) and P. guenoarum (Ramirez-grass).

Correspondence to: Carine Simioni

E-mail: carine.simioni@ufrgs.br
Both are perennials but have different growth habits. Bahiagrass is a creeping grass with aboveground rhizomes, which gives it high resistance to grazing and trampling, while Ramirez-grass is a cespitose grass with basal rhizomes and can reach about a meter high.

Bahiagrass is a predominant species in the grasslands of the southern cone of South America, but is also found in Mato Grosso do Sul, Mato 
Grosso, Paraíba Valley, Minas Gerais, São Paulo and Rio de Janeiro (Maraschin 2001), is perennial and as a forage is widely accepted, with good forage quality, high resistance to grazing and animals trampling (Pozzobon and Valls 1997). The native ecotypes present adaptations to different soil and climate conditions and vary in size of rhizomes and inflorescences and quantity and quality of forage (Nabinger and Dall'Agnol 2008).

The 'Pensacola' cultivar is one of the few alternatives of the Paspalum genus that has seeds commercially available. It is native to eastern Argentina, distributed throughout the provinces of Santa Fe, Corrientes and Entre Rios, and is cultivated in several countries and has been widely used in the Plateau and in the Missions regions of Rio Grande do Sul (I.L. Barreto, unpublished data).

Ramirez-grass on the other hand, is native in the subtropical and temperate regions of southern Brazil, Argentina and Paraguay. In Rio Grande do Sul, it occurs in the Central Depression, Encosta da Serra do Sudeste, Campos de Cima da Serra and Planalto regions (I.L. Barreto, unpublished data). It has a slow initial development, but is very palatable to animals, tolerant to cold and drought, with good distribution of forage production throughout the year (Pedreira et al. 1975). Pereira et al. (2015) and Motta et al. (2016) used the apomictic native ecotypes of Ramirez-grass as male parents in interspecific crosses with Paspalum plicatulum artificially duplicated by colchicine.

For these reasons, this study was carried out in order to verify to what extent the four ecotypes of these grasses differ regarding production and chemical composition of the forage, using cv. 'Pensacola' as a check cultivar.

\section{MATERIALS AND METHODS}

The experiment was carried out at the Agronomic Experimental Station of Federal University of Rio Grande do Sul (UFRGS) (3005’S; 51³9’W,
40 meters above sea level), located in the city of Eldorado do Sul. According to the Köppen (1948), the regional climate is Cfa (subtropical humid with hot summers) and according to the Thornthwaite classification, it is characterized as mesothermal humid, with little water stress and evapotranspiration in the summer, less than $48 \%$ of the annual total. The monthly average temperatures vary between 9 and $25^{\circ} \mathrm{C}$, considering that January and February are the hottest months and June and July the coldest.

The soil of the experimental area is a Paleodult and according to the analysis performed six months before the implementation of the experiment, the soil had a $\mathrm{pH}\left(\mathrm{H}_{2} \mathrm{O}\right)$ of 6.2 ; SMP index of $6.6 ; 1.4$ $\mathrm{mg} / \mathrm{L}$ of phosphorus; $81 \mathrm{mg} / \mathrm{L}$ of potassium; $1.8 \%$ of organic matter; absence of toxic aluminum; 2.2 $\mathrm{cmol}_{\mathrm{c}} / \mathrm{L}$ of calcium and $1.3 \mathrm{cmol}_{\mathrm{c}} / \mathrm{L}$ of magnesium. The soil was corrected with $160 \mathrm{~kg} / \mathrm{ha}$ of $\mathrm{P}_{2} \mathrm{O}_{5}$ in the form of simple superphosphate and $60 \mathrm{~kg} / \mathrm{ha}$ of $\mathrm{K}_{2} \mathrm{O}$ in the form of potassium chloride, being subsequently prepared in the conventional manner, with one plowing and two harrowings.

The experiment was carried out in a completely randomized design with four replicates. An area of approximately $70 \mathrm{~m}^{2}$ divided into 20 plots of 2.0 m X $1.5 \mathrm{~m}$. was used. Two ecotypes of $P$. notatum (André da Rocha and Bagual), and two of $P$. guenoarum (Baio and Azulão) were tested, as well as the cv. 'Pensacola'. The origin of the André da Rocha ecotype is the homonymous city, while the ecotype Bagual originates in the Planalto Médio region, both in the state of Rio Grande do Sul. The ecotypes of $P$. guenoarum were obtained from a collection at the Agronomic Experimental Station of the Federal University of Rio Grande do Sul.

These materials were established through vegetative clones arranged in rows and with a distance of $10 \mathrm{~cm}$ between them. The cutting height was about $2 \mathrm{~cm}$ above soil surface for the ecotypes and the cultivar of $P$. notatum and $10 \mathrm{~cm}$ for $P$. guenoarum, due to the species different growth 
habits, approximately every 30 days. The sample area was defined with a metallic frame of $0.25 \mathrm{~m}^{2}$, inside which the cutting and harvesting of the plant material was done. In each plot two samples were taken, totaling an overall sample area of $0.5 \mathrm{~m}^{2} /$ plot/cut. In total, eight cuts were performed, four in each year of evaluation. After each cut, each plot was fertilized with $50 \mathrm{~kg}$ of $\mathrm{N}$ per hectare as urea.

The material collected in the field was weighed and separated into green leaf blades, stems, inflorescences, dead material and other species, being identified and dried in the oven at $50^{\circ} \mathrm{C}$ for about ten days.

The analysis of the chemical composition was performed with only the leaf blades of the samples from the fourth cut of the first year. These were grounded in the mill and sent to the Food Research Center (CEPA) of UPF in Passo Fundo, where they were analyzed by near-infrared spectroscopy (NIRS).

A completely randomized design was used, with five treatments (ecotypes) and four replicates. In the statistical analysis, the data total dry matter (TDM), leaf dry matter (LDM), inflorescence dry matter (IDM), stem dry matter (SDM) were computed and analyzed with the aid of the statistical package SAS (SAS 2001) and when there was a significance for the F test, the Tukey test at 5\% probability was applied.

\section{RESULTS AND DISCUSSION}

The ecotypes of Ramirez-grass did not differ as to the production of leaf dry matter (LDM), but were significantly higher than the ecotypes of Bahiagrass and cv. 'Pensacola' (Table I). The Azulão produced 2.3 times more leaf blades than the cv. 'Pensacola', and the Bahiagrass ecotypes were about one and a half times superior to this cultivar. Since the leaves are the part of the plant which has the highest nutritional quality, this result is indicative of the forage potential of the tested ecotypes.

In regards to the stem production in the first year, the Baio ecotype had the highest yield, differing significantly from the other materials, except the Azulão ecotype. The bahiagrass ecotypes had the lowest stem productions, with no difference between them (Table I).

As for the variable of inflorescences yield, the Bagual ecotype was superior to all other ecotypes (Table I), indicating a continued increase in growth points and a high potential for seed production. Similar results were found by Lopes and Franke (2011). Regarding the production of inflorescences, the results reveal high inflorescence production for Bagual, indicative of the strength of this native plant and its great potential for multiplication by seeds.

The production of dead material followed the same trend observed for leaf production, with the Ramirez-grass ecotypes presenting higher yields than those of bahiagrass ecotypes (Table I). These values can be attributed mainly to the management employed, which allowed for high forage accumulation and consequently the participation of dead material in its composition.

The yields obtained in the second year (Table II) were lower than those of the first year. The main factor was the drought (100 mm hydric deficit in the months December to February), which forced the end of the evaluations in January of the second year. As a result, the evaluation period during the second year was reduced by two months.

In the second year of evaluation, the TDM, LDM and SDM productions of Azulão were statistically superior to the other ecotypes, which did not differ among themselves. Regarding the production of inflorescences, Bagual had a similar behavior as the previous year, presenting the highest yields, but did not differing statistically from the cv. 'Pensacola'. The Azulão, Baio and André da Rocha ecotypes, however, had the lowest 
TABLE I

Dry matter production of the components of the aerial part and the total, in $\mathrm{kg} / \mathrm{ha}$, of the ecotypes Paspalum spp. and cv. 'Pensacola', in the first year of evaluation, Eldorado do Sul.

\begin{tabular}{cccccc}
\hline Ecotype & LDM** (Leaves) & $\begin{array}{c}\text { SDM** } \\
\text { (Stems) }\end{array}$ & $\begin{array}{c}\text { IDM** } \\
\text { (Inflorescences) }\end{array}$ & $\begin{array}{c}\text { Dead } \\
\text { Material }\end{array}$ & TDM** \\
\hline 'Pensacola' & $4559 \mathrm{c}^{*}$ & $1228 \mathrm{c}^{*}$ & $2840 \mathrm{~b}^{*}$ & $190 \mathrm{c}^{*}$ & $8816 \mathrm{c}^{*}$ \\
A. Rocha & $6931 \mathrm{~b}$ & $661 \mathrm{c}$ & $1018 \mathrm{c}$ & $529 \mathrm{bc}$ & $9138 \mathrm{c}$ \\
Bagual & $7812 \mathrm{~b}$ & $2345 \mathrm{bc}$ & $4009 \mathrm{a}$ & $171 \mathrm{c}$ & $14337 \mathrm{~b}$ \\
Azulão & $11115 \mathrm{a}$ & $4533 \mathrm{ab}$ & $2121 \mathrm{bc}$ & $790 \mathrm{ab}$ & $18560 \mathrm{a}$ \\
Baio & $10501 \mathrm{a}$ & $5505 \mathrm{a}$ & $1175 \mathrm{c}$ & $1053 \mathrm{a}$ & $18243 \mathrm{a}$ \\
\hline
\end{tabular}

* Means followed by the same letters in the same column do not differ statistically by the Tukey test at $5 \%$ significance. ** LDM (leaf dry matter); SDM (stem dry matter); IDM (inflorescence dry matter); TDM (total dry matter).

\section{TABLE II}

Dry matter production of the components of the aerial part, and the total in $\mathrm{kg} / \mathrm{ha}$, of the Paspalum $\mathrm{spp}$. and cv. 'Pensacola' ecotypes in the second year of evaluation, Eldorado do Sul.

\begin{tabular}{ccccccccc}
\hline Species & LDM** (Leaves) & SDM** (Stems) & $\begin{array}{c}\text { IDM** } \\
\text { (Infloresences) }\end{array}$ & $\begin{array}{c}\text { Dead } \\
\text { Material }\end{array}$ & TDM** \\
\hline 'Pensacola' & $4932 \mathrm{~b}^{*}$ & 481 & $\mathrm{~b} *$ & 796 & $\mathrm{ab}$ & $352 \mathrm{ab}^{*}$ & $6561 \mathrm{~b}^{*}$ \\
A Rocha & $5138 \mathrm{~b}$ & 397 & $\mathrm{~b}$ & $315 \mathrm{bc}$ & $139 \mathrm{~b}$ & $5989 \mathrm{~b}$ \\
Bagual & $6201 \mathrm{~b}$ & $293 \mathrm{~b}$ & $1013 \mathrm{a}$ & $205 \mathrm{~b}$ & $7712 \mathrm{~b}$ \\
Azulão & $8279 \mathrm{a}$ & $2220 \mathrm{a}$ & 0 & $\mathrm{c}$ & $681 \mathrm{a}$ & $11180 \mathrm{a}$ \\
Baio & $5782 \mathrm{~b}$ & 869 & $\mathrm{~b}$ & $10 \mathrm{c}$ & $205 \mathrm{~b}$ & $6866 \mathrm{~b}$ \\
\hline
\end{tabular}

* Means followed by the same letters in the same column do not differ statistically by the Tukey test at 5\% significance. ** LDM (leaf dry matter); SDM (stem dry matter); IDM (inflorescence dry matter); TDM (Total dry matter).

productions, which did not differ among each other. This low inflorescence production presented by Baio and Azulão ecotypes was probably due to the time of the cuts, which eliminated a large part of the stems that had already been induced and started elongating.

The results of the total dry matter production were high when compared to other papers, even considering that in the 1 st year we assessed the summer and autumn production and in the 2 nd year, only the spring and part of the summer. In the study by J.C. de Saibro (unpublished data) with Ramirezgrass mixed with other forages, the production was $3800 \mathrm{~kg} / \mathrm{ha}$ of DM, on an average of three years. A.H. Zimmer (unpublished data) reported a total production of this species of $2473 \mathrm{~kg} / \mathrm{ha}$ and 6705 $\mathrm{kg} / \mathrm{ha}$ with the cv. 'Pensacola'. J.A.A. da Costa (unpublished data) found a DM production of over $10,000 \mathrm{~kg} / \mathrm{ha}$ in bahiagrass ecotypes, including André da Rocha.

This work demonstrates, by the data of two years of evaluations, the productive potential of native grasses when appropriate or improved development conditions are available, and could be compared to tropical forage cultivars in Brazil. Acuña et al. (2009) reported that the tetraploid germplasm of bahiagrass is an untapped source of variability that could be explored in the breeding of this species. 
Another important aspect to be addressed is the forage production of Ramirez-grass ecotypes at the end of the growing season, obtained during the last cut, in June of the first year (Table III). This data shows the forage production potential that Azulão and Baio ecotypes present during the fall, a relevant aspect with regard to livestock production in southern Brazil. In this period there is a great forage shortage, known as "autumn forage shortage", since the winter pastures have not yet adequate development for use and summer pastures are at the end of their production cycles.

In the second year, we observed an early spring forage production, especially of the Azulão and Bagual ecotypes, with good DM productions in October, when the first cut was made (Table IV). The TDM production of the André da Rocha ecotype was small, probably since it is less cold tolerant, which occurred in the previous season, but still higher than the productions obtained by Barro et al. (2012) with bahiagrass with a total dry matter production of $441 \mathrm{~kg}$ in four months of growth (December-April), or a monthly accumulation of $110 \mathrm{~kg}$ TDM.

As for the total dry matter production of the second year, although the values were high for the evaluation period, they were below expectations due to the drought that started in mid summer. Still, the materials tested maintained a high production rate, showing the strength and resistance of these species in unfavorable conditions. In this regard, the prospect of using improved cultivars of Ramirezgrass can become an important tool in livestock management in the region when cattle can maintain the gains of spring-summer for a longer period. Another important aspect observed during the study was related to the persistence of ecotypes during the evaluation period. As already highlighted, the cold tolerance of these ecotypes can be considered an essential tool in the development and selection of materials to the weather conditions of this state.

In general, the results show that the $P$. guenoarum ecotypes maintained forage yields higher than the bahiagrass. Among the $P$. notatum ecotypes, Bagual maintained a higher production than the cultivar 'Pensacola' and André da Rocha ecotype.

Considering the production evaluations in colder times of the year, in the climatic conditions of the state of Rio Grande do Sul, there was also superior forage production of $P$. guenoarum ecotypes despite their presenting some visual frost

TABLE III

Total dry matter production in $\mathrm{kg} / \mathrm{ha}$ in each cut in the first year of evaluation of ecotypes of Paspalum spp. and cv. 'Pensacola', EEA-UFRGS, EIdorado do Sul.

\begin{tabular}{|c|c|c|c|c|}
\hline Ecotype & $\begin{array}{c}\text { Cut 1 } \\
\text { Summer } \\
\text { January, 23 }{ }^{\text {th }} \\
\end{array}$ & $\begin{array}{c}\text { Cut } 2 \\
\text { Summer } \\
\text { February, } 27^{\text {th }} \\
\end{array}$ & $\begin{array}{c}\text { Cut } 3 \\
\text { Autumn } \\
{\text { April, } \text { 13 }^{\text {th }}}\end{array}$ & $\begin{array}{c}\text { Cut } 4 \\
\text { Autumn } \\
\text { Juny, 21'h } \\
\end{array}$ \\
\hline 'Pensacola' & $2730 \mathrm{c}^{*}(33)$ & 2960 b (84) & 1821 c (42) & 763 b (11) \\
\hline A Rocha & 3451 bc (42) & 3173 ab (91) & 2363 bc (55) & 693 b (10) \\
\hline Bagual & $5547 \mathrm{ab}(67)$ & $4193 \mathrm{ab}(120)$ & $3652 \mathrm{ab}(85)$ & 945 b (14) \\
\hline Azulão & 6815 a (82) & 5292 a (151) & 4223 a (98) & 2230 a (32) \\
\hline Baio & 7708 a (93) & $4034 \mathrm{ab}(115)$ & 4712 a (109) & 1788 ab (26) \\
\hline
\end{tabular}

* Means followed by the same letters in the same column do not differ statistically by the Tukey test at 5\% significance. Herbage accumulation rates $(\mathrm{kg} / \mathrm{DM} / \mathrm{ha} /$ day $)$ in parentheses. 
TABLE IV

Total dry matter production (TDM) in kg/ha in each cut in the second year of evaluations of ecotypes of Paspalum spp. and cv. 'Pensacola', EEA-UFRGS, Eldorado do Sul.

\begin{tabular}{|c|c|c|c|c|}
\hline Ecotype & $\begin{array}{c}\text { Cut } 1 \\
\text { Spring } \\
\text { October, } 11^{\text {th }} \\
\end{array}$ & $\begin{array}{c}\text { Cut 2 } \\
\text { Spring } \\
\text { November, } 17^{\text {th }}\end{array}$ & $\begin{array}{c}\text { Cut } 3 \\
\text { Spring } \\
\text { December, 09 } \\
\end{array}$ & $\begin{array}{c}\text { Cut } 4 \\
\text { Summer } \\
\text { January, } 19^{\text {th }} \\
\end{array}$ \\
\hline 'Pensacola' & 986 b* (9) & 2550 b (69) & $1699 \mathrm{ab}(77)$ & $1325 \mathrm{~b}(32)$ \\
\hline A Rocha & 740 b (7) & 2010 b (54) & 1306 b (59) & $1933 \mathrm{ab}(47)$ \\
\hline Bagual & $1142 \mathrm{ab}(10)$ & $2404 \mathrm{~b}(65)$ & $1735 \mathrm{ab}(79)$ & $2431 \mathrm{ab}(59)$ \\
\hline Azulão & 2060 a (18) & 3647 a (99) & 2211 a (100) & 3262 a (80) \\
\hline Baio & $1070 \mathrm{~b}(10)$ & $2381 \quad b(64)$ & $1404 \mathrm{ab}(64)$ & $2011 \mathrm{ab}(49)$ \\
\hline
\end{tabular}

* Means followed by the same letters in the same column do not differ statistically by the Tukey test at 5\% significance. Forage accumulation rates $(\mathrm{kg} / \mathrm{DM} / \mathrm{ha} /$ day) in parentheses.

damage. Among the $P$. notatum ecotypes, Bagual was the least susceptible to low temperatures, showing less frost damage than André da Rocha and 'Pensacola'.

Dall'Agnol and Gomes (1987), studying different accessions of Paspalum spp. In a highland region of south Brazil, noted that $P$. guenoarum ecotypes tolerate frost well, by far overcoming cultivars of tropical species. Our study showed that although the species of the genus Paspalum are of summer production, there was a reasonable cold tolerance of the tested ecotypes under the conditions of the Central Depression. On the other hand, the major determinant of the scarce forage production, in the case of $P$. notatum in winter, appears to be dormancy induced by change in photoperiod as occurs locally in mid fall. Work carried out by Sinclair et al. (2001) in Florida with $P$. notatum and Cynodon dactylon ecotypes showed that the cv. 'Pensacola' showed an increase in forage production (3.6 times higher) under the effect of extended photoperiod in the winter when compared to treatment with the absence of this effect. Blount et al. (2001), in the same State, also obtained similar results studying bahiagrass photoperiod response, but the potential forage production during the spring was not decreased due to the increase of photoperiod in autumn-winter.

As for the chemical composition, the $\mathrm{cv}$. 'Pensacola' showed a content of $15.57 \%$ crude protein $(\mathrm{CP})$, followed by Bagual, Azulão, André da Rocha and Baio, where only the Baio ecotype was statistically different from 'Pensacola' (Table V). Regarding the content of neutral detergent fiber (NDF), the 'Pensacola' cultivar presented values of $70.64 \%$, followed by Bagual, Baio, André da Rocha and Azulão ecotypes. 'Pensacola' and Azulão were statistically different (Table V). According to Andrigetto (1983), the daily nutritional needs for growing steers with a live weight of $400 \mathrm{~kg}$, require $9.9 \mathrm{Kg}$ of DM with $8.9 \% \mathrm{CP}$. In this way without any physical restriction to consumption, all ecotypes evaluated properly supply the development of beef cattle.

The results of this study corroborate those found by Scheffer-Basso et al. (2002) that analyzed the total above ground production of cv. 'Pensacola', obtaining values of $14.7 \% \mathrm{CP}, 66.73 \%$ of NDF and $35.98 \%$ of ADF. Soares (1977) compared the André da Rocha ecotype with cv. 'Pensacola' and observed a CP content of $13.42 \%$ for the ecotype and $12.41 \%$ for 'Pensacola'. In the same 
TABLE V

Content of crude protein (CP), neutral detergent fiber (NDF) and acid detergent fiber (ADF) of leaves in four ecotypes of Paspalum and cv. 'Pensacola', Eldorado do Sul.

\begin{tabular}{cccc}
\hline Ecotype & CP & NDF & ADF \\
\hline André da Rocha & $14.49 \mathrm{ab}^{*}$ & $70.47 \mathrm{ab}^{*}$ & $39.29 \mathrm{~b}^{*}$ \\
Bagual & $15.36 \mathrm{ab}$ & $70.6 \mathrm{ab}$ & $39.11 \mathrm{~b}$ \\
'Pensacola' & $15.57 \mathrm{a}$ & $70.64 \mathrm{a}$ & $38.07 \mathrm{~b}$ \\
Azulão & $14.7 \mathrm{ab}$ & $68.78 \mathrm{~b}$ & $40.3 \mathrm{~b}$ \\
Baio & $14.26 \mathrm{~b}$ & $70.55 \mathrm{ab}$ & $43.24 \mathrm{a}$ \\
\hline
\end{tabular}

* Means followed by the same letter in the column do not differ statistically by the Tukey test at $5 \%$ significance.

way, Soares et al. (1986), working with six native ecotypes of $P$. notatum compared to cv. 'Pensacola' for three years, in three different environments from south Brazil, obtained CP levels ranging from $11.50 \%$ to $12.88 \%$.

\section{CONCLUSIONS}

P. guenoarum ecotypes have a potential forage production superior to $P$. notatum ecotypes.

Among the studied ecotypes of P. notatum, Bagual had a greater forage matter production when compared with the 'Pensacola' cultivar.

All materials hold CP, ADF and NDF rates compatible with the minimum requirements for cattle nutrition.

P. guenoarum ecotypes have a higher tolerance to cold than Paspalum notatum ecotypes.

\section{REFERENCES}

ACUÑA CA, BLOUNT AR, QUESENBERRY KH, KENWORTHY KE AND HANNA WW. 2009. Bahiagrass Tetraploid Germoplasm: Reproductive and Agronomic Characterization of Segregating Progeny. Crop Sci 49: 581-588.

ANDRIGETTO JM. 1983. Nutrição animal, v. 2. São Paulo: Nobel, 425 p.

BARRO RS, VARELLA AC, LEMAIRE G, DE MEDEIROS RB, DE SAIBRO JC, NABINGER C, BANGEL FV AND CARASSAI IJ. 2012. Forage yield and nitrogen nutrition dynamics of warm-season native forage genotypes under two shading levels and in full sunlight. R Bras Zootec 41(7): 1589-1597.
BLOUNT AR, SINCLAIR TR, GATES RN, QUESENBERRY KH AND LITTELL RC. 2001. Photoperiod response in 'Pensacola' bahiagrass. In: $19^{\text {th }}$ Annual International Grasslands Congress, Piracicaba. Proceedings.... Piracicaba: Brazilian Society of Animal Husbandry (FEALQ), p. 487-488.

DALL'AGNOL M AND GOMES KE. 1987. Avaliação Inicial da Matéria Seca de Espécies do Gênero Paspalum. In: Encontro Internacional sobre Melhoramento Genético de Paspalum, Nova Odessa. Anais... Nova Odessa: IZ, p. 51-55.

KÖPPEN W. 1948. Climatologia. Cidade do México: Fundo de cultura econômico, $478 \mathrm{p}$.

LOPES RR AND FRANKE LB. 2011. Produção de sementes de quatro ecótipos de Paspalum nativos do Rio Grande do Sul. R Bras Zootec 40(1): 20-30.

MARASCHIN GE. 2001. Production potential of South American grasslands. In: $19^{\text {th }}$ Annual International Grasslands Congress, Piracicaba. Proceedings.... Piracicaba: Brazilian Society of Animal Husbandry (FEALQ), p. 5-15.

MOTTA EAM, NASCIMENTO FL, PEREIRA EA, MACHADO JM, RISSO-BARBOSA M, SIMIONI C AND FERREIRA PB. 2016. Forage performance of hybrid Paspalum obtained from interspecific crosses. Cienc Rural 46: 1025-1031.

NABINGER C. 2006. Manejo e Produtividade das Pastagens Nativas do Subtrópico Brasileiro. In: Simpósio de Forrageiras e Produção Animal, $1^{\circ}$, Canoas. Anais... Canoas: ULBRA, p. 25-75.

NABINGER C AND DALL'AGNOL M. 2008. Principais gramíneas nativas do RS: características gerais, distribuição e potencial forrageiro. In: Simpósio de Forrageiras e Produção Animal, $3^{\circ}$, Porto Alegre. Anais... Porto Alegre: UFRGS, p. 7-54.

PEDREIRA JVS, DE MATTOS HB, MELOTTI L AND DE CAMPOS JR HM. 1975. Stocking rate estimates of grasses associated with legumes. Bol Ind Anim 32(2): 281-292. 
PEREIRA EA, DALL'AGNOL M, SIMIONI C, MACHADO JM, DEBITENCOURT MGS, GUERRAD, ARENHARDT EG AND DA SILVA JAG. 2015. Agronomic performance and interspecific hybrids selection of the genus Paspalum. Científica: Rev Agron 43(4): 388-395.

POZZOBON MT AND VALLS JM. 1997. Chromosome number in germplasm accessions of Paspalum notatum (Gramineae). Braz J Genet 20(1): 29-34.

SAS - STATISTICAL ANALYSES SYSTEM. 2001. SAS: STAT user's guide: statistics. Cary: State University Press; SAS Institute (CR-ROM).

SCHEFFER-BASSO SM, DÜRR JW AND FONTANELI RS. 2002. Valor nutritivo de forragens: concentrados, pastagens e silagens. Passo Fundo: Universidade de Passo Fundo - Centro de Pesquisa em Alimentação, 31 p.

SINCLAIR TR, MISLEVY P AND RAY JD. 2001. Short photoperiod inhibits winter growth of subtropical grasses. Planta 213: 488-491.
SOARES HHPRF. 1977. Efeito de doses de nitrogênio e intervalos entre cortes sobre a produção de matéria seca e proteína bruta de dois ecótipos de Paspalum dilatatum Poir, um ecótipo de Paspalum notatum Flügge e a cultivar 'Pensacola' (Paspalum notatum Flügge var. saurae Parodi). In: Anuário Técnico do Instituto de Pesquisas Zootécnicas "Francisco Osório", Porto Alegre. Anais.. Porto Alegre: Instituto de Pesquisas Zootécnicas Francisco Osório 4: 201-232.

SOARES HHPRF, SILVA VPS, BASSOLS PA, GUTERRES EP AND PERES PS. 1986. Avaliação de ecótipos de Paspalum notatum Flügge e Paspalum nicorae Parodi em comparação com 'Pensacola' (Paspalum saurae Parodi). In: Anuário Técnico do Instituto de Pesquisas Zootécnicas "Francisco Osório", Porto Alegre. Anais... Porto Alegre: Instituto de Pesquisas Zootécnicas Francisco Osório 13(2): 87-119. 